\title{
BCHE Gene
}

National Cancer Institute

\section{Source}

National Cancer Institute. BCHE Gene. NCI Thesaurus. Code C40134.

This gene plays a role in acylcholine hydrolysis and the regulation of myeloid cells. 